\title{
Effect of chitosan coating on surgical sutures to strengthen the colonic anastomosis
}

\author{
Yüksel Altınel, M.D., ${ }^{1}$ Soon Soup Chung, M.D., ${ }^{2}$ ๑ Güven Okay, M.D., ${ }^{3} \odot$ Nesrin Uğraş, M.D., ${ }^{4}$

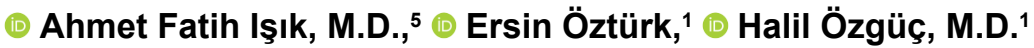

\author{
${ }^{1}$ Department of General Surgery, Uludağ University Faculty of Medicine, Bursa-Turkey \\ ${ }^{2}$ Department of General Surgery, Ewha University Medical Faculty, Seoul-Korea \\ ${ }^{3}$ Department of Biostatistics, Uludağ University Faculty of Medicine, Bursa-Turkey \\ ${ }^{4}$ Department of Pathology, Uludağ University Hospital, Bursa-Turkey \\ ${ }^{5}$ Department of Textile, Uludağ University Faculty of Textile Engineering, Bursa-Turkey
}

\begin{abstract}
BACKGROUND: We evaluated the feasibility of chitosan-coated sutures for intestinal anastomosis strength through wound-healing effect.

METHODS: Vicryl and PDS sutures were coated with $2 \%$ chitosan. While laparotomy was applied to the first group, chitosan was applied in the peritoneal cavity in the second group. Then the following materials were applied to colon anastomosis, in order: Vicryl, PDS, chitosan-coated Vicryl, and chitosan-coated PDS sutures. On the $7^{\text {th }}$ and $14^{\text {th }}$ days, eight rats from each group were euthanized.

RESULTS: The adhesion scores of chitosan and control groups were lower than the suture groups. The vascularization of Vicryl-chitosan was lower than PDS-chitosan on the $14^{\text {th }}$ day $(p=0.038)$. Fibroblast cells and vascularization of anastomosis with chitosan-coated Vicryl were lower than Vicryl and chitosan-coated PDS on the 14th day $(p<0.05)$. The tensile strength of Vicryl-chitosan increased more than Vicryl in vitro $(\mathrm{P}<0.05)$ on the $14^{\text {th }}$ and $7^{\text {th }}$ days, but there was no difference in vivo. The tensile strength of PDS-chitosan decreased more than PDS on the $7^{\text {th }}$ day in vivo $(\mathrm{p}<0.05)$.
\end{abstract}

CONCLUSION: The chitosan-coating effect on the adhesion and reinforcement of anastomosis in some parts of Vicryl in vitro and PDS in vivo was slightly improved.

Keywords: Anastomosis; chitosan; PDS suture; tensile strength; Vicryl suture; wound healing.

\section{INTRODUCTION}

Leakage from colonic anastomosis is caused by multiple factors and results in morbidity and mortality. ${ }^{[1]}$ Anastomotic leakage following colorectal resections occurs in 3\%-23\% of cases. ${ }^{[2]}$ For various reasons, this anastomotic dehiscence is a major problem for anastomotic healing. To reduce this complication, reinforcement of the anastomosis by biological or artificial materials has been tried. Of primary importance are the types of suture materials used for the primary closure of tissues separated by surgical procedures. Numerous sutures with different mechanical properties are used in surgical pro- cedures, which lead to tensile loading. There has been little research on the changes in the mechanical properties of surgical sutures in experimental conditions. ${ }^{[3,4]}$

Peritoneal adhesion formation resulting from tissue ischemia, inflammation, fibrin organization, and collagen formation following abdominal surgeries remains a major problem. ${ }^{[5,6]}$ From various agents that have been used to reduce each of these steps, ${ }^{[5,6]}$ we aimed to investigate chitosan for intra-abdominal inflammatory processes, including adhesion formation and anastomosis strength.

Cite this article as: Altınel Y, Chung SS, Okay G, Uğraş N, Işıı AF, Öztürk E, et al. Effect of chitosan coating on surgical sutures to strengthen the colonic anastomosis. Ulus Travma Acil Cerrahi Derg 2018;24:405-411.

Address for correspondence: Yüksel Altınel, M.D.

Harvard Medical School Boston, United States

Tel: +|8622834536 E-mail:yuksel_altinel@hms.harvard.edu

Ulus Travma Acil Cerrahi Derg 2018;24(5):405-4II DOI: 10.5505/tjtes.2018.59280 Submitted: 30.1 I.20I7 Accepted: II.03.20I8 Online: 10.09.2018

Copyright 2018 Turkish Association of Trauma and Emergency Surgery 
The alkaline deacetylation of chitin obtained from the exoskeleton of crustaceans generates a natural polymer called chitosan. Immunological, antibacterial, wound-healing activity, biodegradability, and hemostatic potential are among the biological properties affected by chitosan. ${ }^{[7,8]}$ We hypothesized that the use of chitosan to suture materials could decrease the dehiscence of colon anastomosis, leakage, and adhesion by preventing inflammation.

Using the multifilament suture VicryITM (Ethicon, Somerville $\mathrm{NJ}$ ) and the monofilament suture PDSTM (Ethicon, Somerville $\mathrm{NJ}$ ), we compared the effectiveness of chitosan-coated sutures with that of non-chitosan-coated sutures in vivo and in vitro. Furthermore, this study measured the effect of chitosan on the tensile strength of different sutures. In this experimental model, we also investigated the effect of chitosan coating on adhesion formation and inflammatory responses.

\section{MATERIALS AND METHODS}

This study was approved by the Medical Faculty of Uludag University, Experimental Animals Production and Research Laboratory Ethical Committee (2010/05/02). The protocols were in compliance with the Declaration of Helsinki.

Ninety-six adult female Wistar albino rats (aged 3 or 4 months, weighing between 250 and $300 \mathrm{~g}$ ) were used. The animals were kept in standard rat cages, with a maximum of four animals per cage, under standard laboratory conditions with pellet food, specifically manufactured for rats and water supplied using a drinking bottle. They were housed at a temperature of $20^{\circ} \mathrm{C}-22^{\circ} \mathrm{C}$, with a relative humidity of $50 \%-60 \%$ and 12-h light-dark cycles. Rats were randomly put into six groups, of 16 rats each, and were further divided into groups of eight rats for evaluation on the $7^{\text {th }}$ and $14^{\text {th }}$ days to compare outcomes.

\section{Experimental Groups}

Group I: The control group; only laparotomy was performed on 16 rats. Then, eight rats from each group were sacrificed on the $7^{\text {th }}$ and $14^{\text {th }}$ days.

Group 2: The chitosan group; only $100 \mathrm{mg}$ of chitosan powder was applied into the peritoneal cavity over the distal part of the cecum following dry gauze repeatedly rubbed to cause sub-serosal bleeding in 16 rats. Then, eight rats from each group were sacrificed on the $7^{\text {th }}$ and $14^{\text {th }}$ days.

Group 3: The Vicryl suture was used to perform a colon anastomosis after cecal enterotomy on 16 rats. Then, eight rats from each group were sacrificed on the $7^{\text {th }}$ and $14^{\text {th }}$ days.

Group 4: The 5/0 PDS suture was used to perform a colon anastomosis after cecal enterotomy on 16 rats. After that eight rats for each group were sacrificed on the $7^{\text {th }}$ and $14^{\text {th }}$ days.
Group 5: The chitosan-coated 5/0 Vicryl sutures were used to perform a colon anastomosis after cecal enterotomy on 16 rats. Then, eight rats from each group were sacrificed on the $7^{\text {th }}$ and $14^{\text {th }}$ days.

Group 6: The chitosan-coated 5/0 PDS sutures were used to perform a colon anastomosis after cecal enterotomy on 16 rats. Then, eight rats from each group were sacrificed on the $7^{\text {th }}$ and $14^{\text {th }}$ days.

\section{The Chitosan-Coating Procedure}

The chitosan (Sigma, MO, USA) powder was added to a $1 \%$ ( $\mathrm{ml}$ acetic acid, $99 \mathrm{ml}$ water) acetic acid (100\%, Merck, Germany) solution to prepare a $2 \%$ (2 g chitosan, $98 \mathrm{~g}$ acetic acid solution) chitosan solution. Then, 5/0 PDS and 5/0 Vicryl sutures were placed into the $2 \%$ chitosan solution and incubated for $30 \mathrm{~min}$. The sutures were then warmed at $30^{\circ} \mathrm{C}$ in an oven in a textile engineering laboratory. Sterilization of the sutures was performed later.

\section{Surgical Procedures}

All animals were fasted overnight before surgery. Anesthesia was maintained with an injection of $10 \mathrm{mg} / \mathrm{kg}$ intramuscular ketamine (Ketalar, Phizer, AUSTR) and I mL/kg xylazine (Rompun, Bayer, Germany).

An 8-cm midline incision was made on the abdomen after antisepsis by povidone iodine application. Segments of colon approximately $2 \mathrm{~cm}$ distal to the cecum were identified and partially transected, following which continuity was restored by anastomosis using a single layer of continuous $5 / 0$ Vicryl or 5/0 PDS sutures.

Moreover, we only performed laparotomy in the control group. The laparotomy closure was performed via a continuous suture technique using 000 polypropylene (Prolene, Ethicon Inc., Somerville, NJ, USA). The skin was closed using a surgical stapler.

On the $7^{\text {th }}$ postoperative day, eight randomly chosen rats from each group were sacrificed by cervical dislocation. The others were sacrificed on the $14^{\text {th }}$ day. Through the initial laparotomy scar, the abdomen was opened in a cranialto-caudal manner by midline incision in order to view the exact intra-abdominal adhesion formations. In the suture groups, anastomotic segments, including the anastomosis in the middle surrounding colon tissue, and adhesions of approximately $6 \times 3 \mathrm{~cm}$ were carefully resected. In the chitosan group, the damaged cecum area was excised. The specimens were washed in saline, and stool was removed from the lumen. The anastomotic tissue around sutures a $4 \times 3 \mathrm{~cm}$ wide strips was taken for the tensile strength of sutures, and a $2 \times 1 \mathrm{~cm}$ tissue of anastomosis was taken for histopathological evaluation. 
Table I. Adhesion grading according to Diamond classification

\begin{tabular}{lccc}
\hline Score & Extent & Tenacity & Type \\
\hline 0 & $0 \%$ & None & None \\
1 & $<25 \%$ & Easily lysed & Filmy, no vessels \\
2 & $25-50 \%$ & Lysed with traction & Opaque, no vessels \\
3 & $50-75 \%$ & Required sharp dissection & Opaque, small vessels \\
4 & $>75 \%$ & & Opaque, large vessels \\
\hline
\end{tabular}

Table 2. Histologic grading scale for inflammatory cell infiltration, blood vessel and fibroblast ingrowth and collagen deposition

$\begin{array}{ll}0 & \text { No evidence } \\ 1 & \text { Occasional evidence } \\ 2 & \text { Light scattering } \\ 3 & \text { Abundant evidence } \\ 4 & \text { Confluent cells or fibers }\end{array}$

\section{Evaluation of Adhesion Formation}

The adhesions were graded according to the Diamond classification by a general surgeon who had no knowledge about each rat's groups (Table I). ${ }^{[9]}$

\section{Histological Evaluation}

A pathologist blinded to the methods and groups examined all the specimens. Through this examination, efficacy of the interaction among the chitosan, sutures, and cecum could be observed. The tissues were fixed in a $10 \%$ buffered formaldehyde solution. The tissues were then embedded in paraffin following dehydration. The 5 - $\mu \mathrm{m}$ thick sections were stained with hematoxylin and eosin and then evaluated by light microscopy at a magnification of 200x. The histopathological grading was performed with a modified Ehrlich and Hunt numerical scale (Table 2). ${ }^{[10]}$

\section{In Vivo and In Vitro evaluation of Sutures' Tensile Strength}

The anastomotic site surrounding the sutures was resected as a $4 \times 3-\mathrm{cm}$ wide strip for tensile strength. The sutures were then separated from the tissue for in vivo measurements. Also, Vicryl and PDS sutures were put into serum for in vitro measurements until the $7^{\text {th }}$ and $14^{\text {th }}$ days.

The tests were evaluated in an Instron (Norwood, MA, USA) $4,30 \mathrm{I}$ instrument at room temperature, $21^{\circ} \mathrm{C}$. The force employed was $5 \mathrm{kN} / \mathrm{min}$. This action was established in the longitudinal direction in order to maintain the maximum strength at disruption. ${ }^{[5]}$

\section{Statistical Analysis}

The adhesion, tensile strength, and histopathological scores were compared with Kruskal-Wallis test and Mann-Whitney $U$-test for intergroup comparisons to evaluate the data. The results were showed as median (minimum-maximum). SPSS 23.0 software (Chicago, IL, USA) was used. A p value $<0.05$ on a 2-tailed test was considered statistically significant.

\section{RESULTS}

One rat each from Vicryl and Vicryl-chitosan-coated groups and two from PDS group died after the intervention for unidentified reasons. Throughout the investigation, no infections or anastomosis leakage were found. Additionally, the differences in weight and diameter of the sutures were not determined statistically significant.

\section{Adhesion Score (Fig. 1a, b)}

The adhesion score groups were listed in Table 3 . When the adhesion scores on the $7^{\text {th }}$ and $14^{\text {th }}$ days were evaluated, a significant difference between the suture groups was not identified $(p>0.05)$. The adhesion score of Vicryl and PDS groups were higher than the chitosan and control groups when comparing each on the $7^{\text {th }}$ day $(p<0.05)$. Also, there was no significant difference between the chitosan and control groups. Even though the adhesion score of the chitosan and control groups was lower than suture groups, the PDS group adhesion score was statistically higher than chitosan on the $14^{\text {th }}$ day $(p<0.05)$. In addition, clinically the adhesion scores of chitosan-coated Vicryl and PDS groups observed a minimal decrease at the $14^{\text {th }}$ day compared with the $7^{\text {th }}$ day.
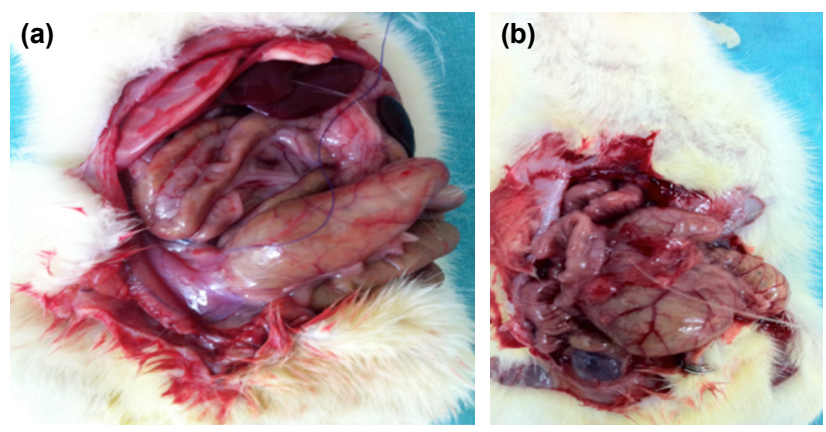

Figure 1. The intra-abdominal adhesion of (a) the Vicryl suture and (b) PDS suture. 
Table 3. The scores of adhesions

\begin{tabular}{|c|c|c|c|c|c|c|c|}
\hline & Control & Chitosan & Vicryl & Polydioxanone & Vicryl Chitosan & Polydioxanone Chitosan & $\mathbf{p}^{*}$ \\
\hline $7^{\text {th }}$ & $0(0-I)$ & $0(0-1)$ & $2.5(I-3)$ & $2(I-3)$ & I (0-2) & $1.5(0-2)$ & $<0.001^{*}$ \\
\hline $14^{\text {th }}$ & $I(0-I)$ & $0(0-1)$ & $I(I-2)$ & $2(I-3)$ & $0.5(0-2)$ & I (0-2) & $0.012^{*}$ \\
\hline$P$ & 0.234 & I & 0.094 & 0.383 & 0.281 & 0.279 & \\
\hline
\end{tabular}

*Statistically significant.

Table 4. Comparison of $7^{\text {th }}$ and $14^{\text {th }}$ day histopathological values of groups

\begin{tabular}{|c|c|c|c|c|c|c|c|}
\hline & & Chitosan & Vicryl & Polydioxanone & Vicryl Chitosan & Polydioxanone Chitosan & $\mathbf{p}$ \\
\hline \multirow[t]{3}{*}{ Inflammatory cell } & $7^{\text {th }}$ day & $1.25(I-2)$ & $3(2-3)$ & $3(2-3)$ & $2(2-3)$ & $3(3-3)$ & $<0.00$ I $^{*}$ \\
\hline & $14^{\text {th }}$ day & $\mathrm{I} .5(\mathrm{I}-3)$ & $3(2-3)$ & $3(2-3)$ & $2.5(2-3)$ & $3(2-3)$ & $0.01 I^{*}$ \\
\hline & $\mathrm{P}$ & 0.645 & 0.779 & I & 0.867 & 0.234 & \\
\hline \multirow[t]{3}{*}{ Fibroblast } & $7^{\text {th }}$ day & $0.87(0-2)$ & $2(1-3)$ & $2(0-3)$ & I (0-2) & $2(I-2)$ & $0.019^{*}$ \\
\hline & $14^{\text {th }}$ day & $0.87(0-2)$ & $2(2-3)$ & $2(2-2)$ & $I(I-2)$ & $2(I-2)$ & $<0.00 I^{*}$ \\
\hline & $\mathrm{P}$ & 1 & $0.28 I$ & 0.383 & 0.867 & 0.442 & \\
\hline \multirow[t]{3}{*}{ Neovascularization } & $7^{\text {th }}$ day & $0.75(0-2)$ & $2(I-2)$ & $2(I-3)$ & I (0-2) & $2(1-2)$ & $0.010^{*}$ \\
\hline & $14^{\text {th }}$ day & $\mathrm{I} .75(\mathrm{I}-3)$ & $2(2-3)$ & $2(I-2)$ & $I(I-2)$ & $2(2-2)$ & $0.013^{*}$ \\
\hline & $\mathrm{P}$ & 0.5 & 0.072 & 0.71 & 0.613 & 0.234 & \\
\hline \multirow[t]{3}{*}{ Collagen } & $7^{\text {th }}$ day & $0.75(0-2)$ & $0.5(0-1)$ & I $(0-2)$ & $0(0-0)$ & $3(0-3)$ & $0.009^{*}$ \\
\hline & $14^{\text {th }}$ day & I. $125(0-2)$ & $I(0-1)$ & $0(0-1)$ & $0(0-1)$ & $0(0-1)$ & $0.025^{*}$ \\
\hline & $\mathrm{P}$ & 0.328 & 0.867 & 0.318 & 0.463 & 0.442 & \\
\hline
\end{tabular}

"Statistically significant.

\section{Histopathology (Fig. 2a, b)}

The histopathological evaluation was shown in Table 4. The fibroblast cell accumulation and vascularization on the $14^{\text {th }}$ day in the Vicryl-chitosan group were significantly lower than those in the Vicryl group $(p=0.009)$ compared with the other suture groups. Additionally, the vascularization of the Vicryl-chitosan group was observed significantly lower than the PDS-chitosan group on the $14^{\text {th }}$ day $(p=0.038)$. However, there wasn't any statistical difference between suture groups on the $7^{\text {th }}$ day among inflammatory changes $(p>0.05)$. Histopathologically, no statistically significant difference was observed between suture groups of anastomosis for inflammatory cell and collagen accumulation $(p>0.05)$. However, the chitosan group had a lower amount of neovascularization,
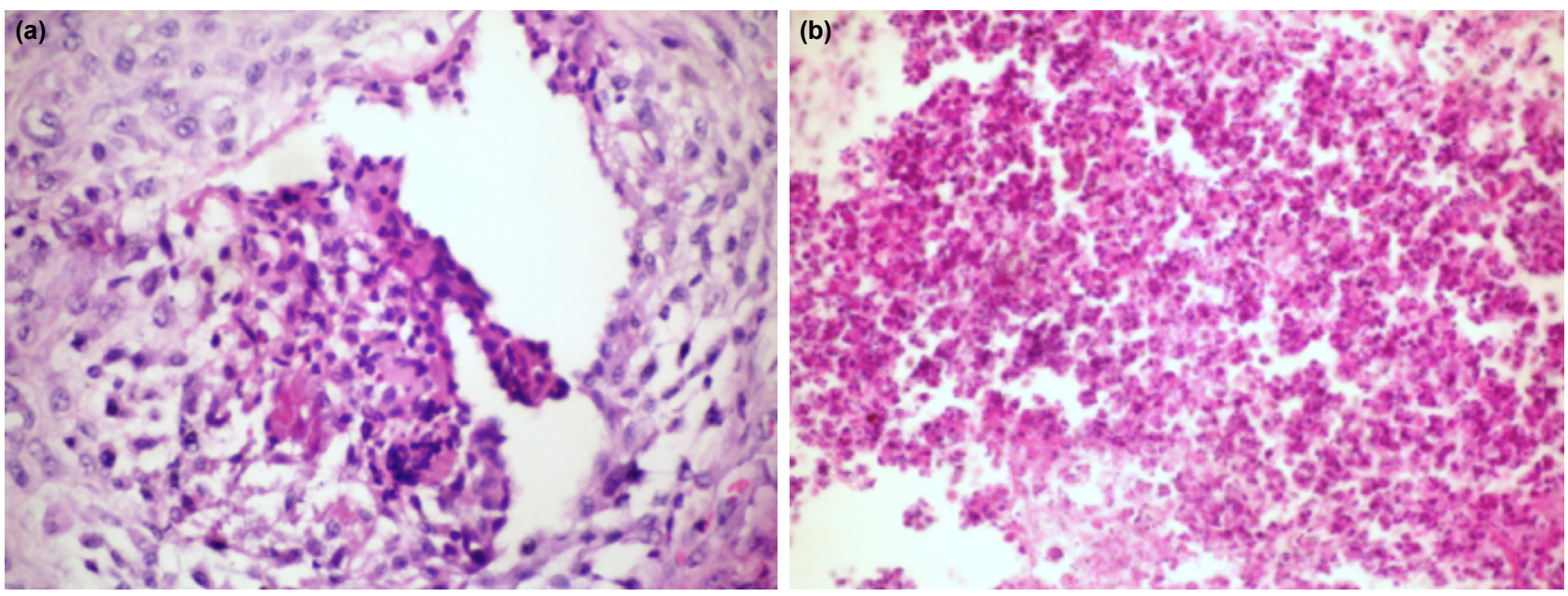

Figure 2. The inflammatory cell infiltration of (a) the Vicryl suture (H\&E 10) and (b) PDS suture (H\&E 10). 
Table 5. The tensile strength of sutures $(\mathrm{MPa})$ as median (min-max) value

\begin{tabular}{|c|c|c|c|c|}
\hline & & $7^{\text {th }}$ & $14^{\text {th }}$ & $\mathbf{p}$ \\
\hline \multirow[t]{3}{*}{ Vicryl } & In vivo & $0.0214(0.019-0.0256)$ & $0.0165(0.0159-0.0172)$ & $<0.001^{*}$ \\
\hline & In vitro & $0.0184(0.0183-0.0188)$ & $0.0017(0.0016-0.0018)$ & $<0.001^{*}$ \\
\hline & $\mathrm{P}$ & $0.012^{*}$ & $0.018^{*}$ & \\
\hline \multirow[t]{3}{*}{ Polydioxanone } & In vivo & $0.0195(0.0176-0.0202)$ & $0.0177(0.0162-0.0188)$ & $0.007^{*}$ \\
\hline & In vitro & $0.0256(0.0251-0.0262)$ & $0.0025(0.0024-0.0026)$ & $0.00 I^{*}$ \\
\hline & $\mathrm{P}$ & $0.018^{*}$ & $0.018^{*}$ & \\
\hline \multirow[t]{3}{*}{ Vicryl Chitosan } & In vivo & $0.0194(0.0161-0.0249)$ & $0.01535(0.0125-0.0208)$ & $0.021^{*}$ \\
\hline & In vitro & $0.0246(0.023 I-0.026 I)$ & $0.02465(0.0236-0.0257)$ & 0.694 \\
\hline & $\mathrm{P}$ & $0.028^{*}$ & $0.012^{*}$ & \\
\hline \multirow[t]{3}{*}{ Polydioxanone Chitosan } & In vivo & $0.017(0.0156-0.0176)$ & $0.016(0.0149-0.0174)$ & 0.161 \\
\hline & In vitro & $0.0252(0.025-0.0254)$ & $0.0023(0.002-0.0025)$ & $<0.001^{*}$ \\
\hline & $\mathrm{P}$ & $0.012^{*}$ & $0.012^{*}$ & \\
\hline$P$ & & $<0.05^{*}$ & $<0.05^{*}$ & \\
\hline
\end{tabular}

"Statistically significant.

fibroblast, and inflammatory cell accumulation and higher amount of collagen accumulation than the suture groups on the $7^{\text {th }}$ and $14^{\text {th }}$ days $(p<0.05)$. It was evident that the chitosan had an influence over the Vicryl suture causing minimal decrease among fibroblast, inflammatory cell and collagen accumulation including vascularization on the $14^{\text {th }}$ day. However, no histopathological major change was observed among the chitosan effect on the PDS suture on the $14^{\text {th }}$ day $(p>0.05)$.

\section{In Vivo and In Vitro Evaluation of Sutures' Tensile Strength}

The tensile strength data for these groups were arranged in Table 5.

The tensile strength of Vicryl was statistically lower than PDS in vivo and in vitro on the $14^{\text {th }}$ day and the $7^{\text {th }}$ day $(p<0.05)$. The tensile strength of the PDS's $14^{\text {th }}$ day was lower than PDS's $7^{\text {th }}$ day, in vivo $(p=0.007)$ and in vitro $(p=0.001)$. The tensile strength of Vicryl's $14^{\text {th }}$ day was lower than Vicryl's $7^{\text {th }}$ day, in vivo and in vitro $(\mathrm{p}<0.00 \mathrm{I})$.

The chitosan decreased the tensile strength of PDS after coating in vivo and in vitro on the $7^{\text {th }}$ and $14^{\text {th }}$ days. Even if the tensile strength of PDS-chitosan decreased in vitro more than PDS on $7^{\text {th }}$ day, statistically significant decline was seen in vivo $(\mathrm{p}<0.05)$. However, the tensile strength of PDS-chitosan decreased more on the $14^{\text {th }}$ day than on the $7^{\text {th }}$ day in vivo $(p=0.16 \mathrm{I})$; hence, a significant decline was seen in vitro $(p<0.001)$.

The chitosan decreased the tensile strength of Vicryl after coating in vivo but increased the tensile strength of Vicryl after coating in vitro on the $7^{\text {th }}$ and $14^{\text {th }}$ days. The tensile strength of Vicryl-chitosan on the $14^{\text {th }}$ day had significantly decreased in vivo $(p=0.021)$ more than the $7^{\text {th }}$ day, but there was no statistical difference in vitro $(p=0.694)$. The tensile strength of Vicryl-chitosan had significantly increased in vitro $(p<0.05)$ more than Vicryl on the $14^{\text {th }}$ and $7^{\text {th }}$ days, but there was no statistical difference in vivo. The tensile strength of Vicryl-chitosan had decreased in vitro more than PDS-chitosan's on the $7^{\text {th }}$ day, but Vicryl-chitosan was statistically more than PDS-chitosan's tensile strength in vivo $(\mathrm{p}=0.09)$ on the $7^{\text {th }}$ day. Vicryl-chitosan had significantly increased in vitro $(\mathrm{p}<0.05)$ more than PDS-chitosan's tensile strength on the $14^{\text {th }}$ day, but there were no significant differences in vivo.

\section{DISCUSSION}

The chitosan coating on multifilament sutures such as VicryITM (Ethicon, Somerville NJ) and monofilament PDSTM (Ethicon, Somerville NJ) was evaluated according to adhesion formation, histopathology, and tensile strength. In our experimental model, the coating of sutures with chitosan provided clinically beneficial effects to intra-abdominal adhesion formation. Moreover, when we respectively considered the evaluation of tensile strength in vivo and in vitro, we realized that there are some different interactions between the biocompatibility of sutures.

Chitosan has an essential effect on the inhibition of fibroblast migration and the reduction of collagen deposition at the surgical site..$^{[1-13]}$ The modified chitosan films such as $100 \%$ chitosan film, forms containing $10 \%$ or $50 \%$ gelatin, $\mathrm{N}$, O-carboxymethyl chitosan gel and NOCC $2 \%$ solution forms were used in some of the experimental models. The modified chitosan film and gelatin forms have an effect on preventing peritoneal adhesions. ${ }^{[14-16]}$ In vivo and in vitro the intestine tissue was repaired by laser-activated chitosan adhesive for achiev- 
ing the repair strength. ${ }^{[17]}$ Furthermore, one of the features of chitosan is its hemostatic potential to prevent postoperative intra-abdominal bleeding which is a stimulus for adhesion. ${ }^{[8]}$ However, similar to the study of the chitosan coating over meshes, ${ }^{[5]}$ we did not observe any statistically significant decrease in peritoneal adhesion formation after the application of a chitosan on the sutures when compared to the uncoated forms. We can only mention that the beneficial influence of chitosan clinically observed during one of the inflammatory processes of adhesion formation had a collaborative effect on anastomosis strength.

In addition to that, there was not enough statistically significant difference between suture groups related to anastomosis for inflammatory cell and collagen accumulation in our study. The vascularization of Vicryl-chitosan group was observed to be significantly less than Vicryl and PDS-chitosan. In addition, the fibroblast cell accumulation of Vicryl-chitosan group is significantly less than Vicryl on the $14^{\text {th }}$ day. Due to this, a correlation could be made that the tensile strength of chitosan-coated Vicryl might be decreased in vivo. Our results could be due to the interaction of the chitosan coating and the property of multifilament VicryITM. The fibroblast cell accumulation associated with inflammation promotes the adhesion formation and fibrosis involving collagen accumulation. ${ }^{7,18]}$ The adhesion score was lower in the chitosan group, although the suture groups were not strongly affected by the chitosan coating. However, it was estimated that the insufficient determination of the pathological results for anastomosis strength could be dependent on the amount of chitosan, the technique of coating or the type of suture material.

Moreover, there are many different biological and artificial materials for the prevention of anastomotic leakage and the reinforcing of anastomosis by covering it, like Bio-Gide, grafts, meshes, ${ }^{[2]}$ which have been investigated. In addition, the bio-sutures like the mesenchymal stem cell-coated suture, ${ }^{[19]}$ albumin-coated bioactive suture, ${ }^{[20]}$ IGF-I-coated sutures, ${ }^{[21]}$ protein-coated sutures ${ }^{[22]}$ were used in various types of wound-healing processes. Some treatment effects of the resveratrol, gentamicin, fibrin glue, and butyrate on the healing of colonic anastomosis were performed in the studies. $[1,23]$ In our experiment, we evaluated the multifilament and monofilament sutures by coating with chitosan to encourage the cellular adhesion via inflammatory processes for reinforcing the anastomosis.

On the other hand, the weakest but main difference of our study compared with others is related to the evaluation of the bursting pressure of anastomosis. ${ }^{[24]}$ The lack of proof by one of the measurements is the bursting pressure of the anastomotic strength. ${ }^{[25]}$ When we investigated the breaking strength of anastomosis, we determined the tensile strength of sutures by evaluating the tensile strength of sutures in vivo and in vitro. We observed that chitosan interaction was more evident at chitosan-coated Vicryl in vitro and chitosan- coated PDS in vivo. Although there were few different examples of chitosan biocompatibility or Nano-technics including electrospinning and new approaches to the development of suture materials. ${ }^{[26,27]}$ According to recent experiments, as we observed, the newly developed suture coating process concludes as a promising method for obtaining a beneficial antibacterial effect. Similarly, to our study, it appears that the coating slightly improved the tensile strength of the sutures after the application of natural coatings on non-absorbable sutures. ${ }^{[28,29]}$

Consequently, the results of our experiment did partially support our hypothesis. The chitosan coating over the sutures ameliorates the adhesion scores, the tensile strength, or the histopathological criteria in some parts over the reinforcement of anastomosis. The chitosan coating on the adhesion potential has shown clinically beneficial effects compared to statistical results. In addition, the chitosan improved the reinforcement of anastomosis in some parts of Vicryl in vitro and PDS in vivo. It is obvious that further investigations are required for the definitive clinical usage with new technical approaches for the chitosan-coated sutures among the anastomosis reinforcement. Moreover, there will be new challenges to create different suture properties.

\section{Acknowledgments}

This study was presented as a poster at the ESCP $8^{\text {th }}$ Scientific and Annual Meeting, 25-27 September 2013, Belgrade.

\section{Conflict of interest: None declared.}

\section{REFERENCES}

1. Subhas G, Bhullar JS, Cook J, Shah A, Silberberg B, Andrus L, et al. Topical gentamicin does not provide any additional anastomotic strength when combined with fibrin glue. Am J Surg 2011;201:339-43.

2. Hoeppner J, Willa K, Timme S, Tittelbach-Helmrich D, Hopt UT, Keck $\mathrm{T}$, et al. Reinforcement of colonic anastomoses with a collagenous doublelayer matrix extracted from porcine dermis. Eur Surg Res 2010;45:6876. [CrossRef]

3. Kim JC, Lee YK, Lim BS, Rhee SH, Yang HC. Comparison of tensile and knot security properties of surgical sutures. J Mater Sci Mater Med 2007;18:2363-9. [CrossRef]

4. Hernandez KA, Hooper RC, Boyko T, Golas AR, van Harten M, Wu $\mathrm{DQ}$, et al. Reduction of suture associated inflammation after 28 days using novel biocompatible pseudoprotein poly(ester amide) biomaterials. J Biomed Mater Res B Appl Biomater 2015;103:457-63. [CrossRef]

5. Altınel Y, Öztürk E, Özkaya G, Akyıldız EÜ, Ulcay Y, Özgüç H. The effect of a chitosan coating on the adhesive potential and tensile strength of polypropylene meshes. Hernia 2012;16:709-14. [CrossRef]

6. Altınel Y, Taşpınar E, Ozgüç H, Oztürk E, Ulker Akyıldız E, Bağdaş D. The protective effect of ClinOleic against post-surgical adhesions. Ulus Travma Acil Cerrahi Derg 2014;20:1-6. [CrossRef]

7. Gómez-Estaca J, López de Lacey A, López-Caballero ME, Gómez-Guillén $\mathrm{MC}$, Montero P. Biodegradable gelatin-chitosan films incorporated with essential oils as antimicrobial agents for fish preservation. Food Microbiol 2010;27:889-96. [CrossRef]

8. Ong SY, Wu J, Moochhala SM, Tan MH, Lu J. Development of a chi- 
tosan-based wound dressing with improved hemostatic and antimicrobial properties. J Biomaterials 2008;29:4323-32. [CrossRef]

9. Schneider A, Bennek J, Olsen K. Experimental study evaluating the effect of a barrier method on postoperative intraabdominal adhesions. Dig Dis Sci 2006;51:566-70. [CrossRef]

10. Phillips JD, Kim CS, Folkalsrud EW. Effects of chronic corticosteroids and vitamin A on the healing of intestinal anastomoses. Am J Surg 1992;163:71-7. [CrossRef]

11. Zhou J, Elson C, Le TD. Reduction in postoperative adhesion formation and re-formation after an abdominal operation with the use of $\mathrm{N}, \mathrm{O}$ carboxymethyl chitosan. J Surg 2004;135:307-12.

12. Risbud M, Hardikar A, Bhonde R. Growth modulation of fibroblasts by chitosan-polyvinyl pyrrolidone hydrogel: implications for wound management? J Biosci 2000;25:25-31. [CrossRef]

13. van der Wal JB, Jeekel J. Biology of the peritoneum in normal homeostasis and after surgical trauma. Colorectal Dis 2007;9:9-13. [CrossRef]

14. Zhang $\mathrm{Z}, \mathrm{Xu} S$, Zhou XL. Preventive effects of chitosan on peritoneal adhesion in rats. WJ Gastroenterol 2006; 28:4572-77.

15. Zhou X, Chen S, Liao G, Shen ZJ, Zhang ZL, Sun L, et al. Preventive effect of gelatinizedly-modified chitosan film on peritoneal adhesion of different types. World J Gastroenterol 2007;13:1262-67. [CrossRef]

16. Costain DJ, Kennedy R, Ciona C McAlister VC, Lee TD. Prevention of postsurgical adhesions with $\mathrm{N}, \mathrm{O}$-carboxymethyl chitosan: examination of the most efficacious preparation and the effect of N,O-carboxymethyl chitosan on postsurgical healing. J Surg 1997;121:314-19.

17. Lauto A, Stoodley M, Marcel H, Avolio A, Sarris M, McKenzie G, et al. In vitro and in vivo tissue repair with laser-activated chitosan adhesive. Lasers Surg Med 2007;39:19-27. [CrossRef]

18. Bachman S, Ramshaw B. Prosthetic material in ventral hernia repair: how do I choose? Surg Clin N Am 2008;88:101-12. [CrossRef]

19. Pascual I, Fernández de Miguel G, García Arranz M, García-Olmo D. Biosutures improve healing of experimental weak colonic anastomoses. Int J Colorectal Dis 2010;25:1447-51. [CrossRef]
20. Horváthy DB, Vácz G, Cselenyák A, Weszl M, Kiss L, Lacza Z. Albumin-coated bioactive suture for cell transplantation. Surg Innov 2013;20:249-55. [CrossRef]

21. Rijcken E, Fuchs T, Sachs L, Kersting CM, Bruewer M, Krieglstein CF. Insulin-like growth factor 1-coated sutures improve anastomotic healing in an experimental model of colitis. Br J Surg 2010;97:258-65. [CrossRef]

22. Mazzocca AD, McCarthy MB, Arciero C, Jhaveri A, Obopilwe E, Rincon $\mathrm{L}$, et al. Tendon and bone responses to a collagen-coated suture material. J Shoulder Elbow Surg 2007;16:222-30. [CrossRef]

23. Cakmak GK, Irkorucu O, Ucan BH, Tascilar O, Emre AU, Karakaya K, et al. The effects of resveratrol on the healing of left colonic anastomosis. J Invest Surg 2009;22:353-61. [CrossRef]

24. Månsson $\mathrm{P}$, Zhang XW, Jeppsson B, Thorlacius H. Anastomotic healing in the rat colon: comparison between a radiological method, breaking strength and bursting pressure. Int J Colorectal Disease 2002;17:4205. [CrossRef]

25. Posma LA, Bleichrodt RP, Lomme RM, de Man BM, van Goor H, Hendriks T. Early anastomotic repair in the rat intestine is affected by transient preoperative mesenteric ischemia. J Gastrointest Surg 2009;13:1099-106. [CrossRef]

26. Sanders D, Lambie J, Bond P, Moate R, Steer JA. An in vitro study assessing the effect of mesh morphology and suture fixation on bacterial adherence. Hernia 2013;17:779-89. [CrossRef]

27. Norowski PA, Mishra S, Adatrow PC, Haggard WO, Bumgardner JD. Suture pullout strength and in vitro fibroblast and RAW 264.7 monocyte biocompatibility of genipin crosslinked nanofibrous chitosan mats for guided tissue regeneration. J Biomed Mater Res A 2012;100:2890-6.

28. Debbabi F, Gargoubi S, Hadj Ayed MA, Abdessalem SB. Development and characterization of antibacterial braided polyamide suture coated with chitosan-citric acid biopolymer. J Biomater Appl 2017;32:384-98.

29. Masood R, Hussain T, Umar M, Azeemullah, Areeb T, Riaz S. In situ development and application of natural coatings on non-absorbable sutures to reduce incision site infections. J Wound Care 2017;26:115-20.

\section{DENEYSEL ÇALIŞMA - ÖZET}

\section{Kitosan kaplı ipliklerin anastomoz gücü arttırma üzerine etkisi \\ Dr. Yüksel Altınel, ${ }^{1}$ Dr. Soon Soup Chung, ${ }^{2}$ Dr. Güven Okay, ${ }^{3}$ Dr. Nesrin Uğraş, ${ }^{4}$ Dr. Ahmet Fatih Işık, ${ }^{5}$ Dr. Ersin Öztürk, ${ }^{1}$ Dr. Halil Özgü̈ç ${ }^{1}$}

${ }^{1}$ Uludağ Üniversitesi Tip Fakültesi, Genel Cerrahi Anabilim Dalı, Bursa

Ewha Üniversitesi Hastanesi, Genel Cerrahi Anabilim Dalı, Seul-Kore

${ }^{3}$ Uludağ Üniversitesi Tip Fakültesi, Biostatistics Anabilim Dalı, Bursa

${ }^{4}$ Uludağ Üniversitesi Tip Fakültesi, Patoloji Anabilim Dalı, Bursa

${ }^{5}$ Uludağ Üniversitesi Tekstil Mühendisliği Fakültesi, Tekstil Anabilim Dalı, Bursa

AMAÇ: Yara iyileşmesi etkisiyle, kitosan kaplı ipliklerin bağırsak anastomozu gücü üzerine uygulanabilir olmasını araştırdık.

GEREÇ VE YÖNTEM: Vikril ve PDS iplikler \%2 kitosanla kaplandı. Laparatomi birinci gruba uygulanırken, kitosan ikici grupta periton boşluğuna uygulandı. Takibinde sırasıyla vikril, PDS, kitosan kaplı vikril ve kitosan kaplı PDS iplikler kolon anastomozunda kullanıldı. Yedinci ve I4. günlerde her gruptan sekiz sıçan sakrifiye edilerek incelemesi yapıldı.

BULGULAR: Kitosan ve kontrol grubunun adezyon değeri iplik gruplarına göre anlamlı olarak daha düşük saptandı $(p<0.05)$. Kitosan kaplı vikril grubunun 14. günde vaskülarizasyon değeri, kitosan kaplı PDS iplik grubuna göre anlamlı olarak daha az olduğu belirlendi $(p=0.038)$. Kitosan kaplı vikrilin I4. gücünde, anastomoz vaskülarizasyonu ve fibroblast hücreleri üzerinde vikril ve kitosan kaplı PDS göre etkisi daha düşük bulundu $(p<0.05)$. Kitosan kaplı vikrilin I4. ve yedinci günündeki in vitro mukavemet gücü vikrilden daha yüksek olmasına rağmen $(p<0.05)$, in vivo farklılık görülmedi. The PDS-kitosan'ın mukavemet gücü in vivo yedinci günde, PDS'den daha az olarak saptandı $(p<0.05)$.

TARTIŞMA: Kitosan ile kaplama, anastomoz gücünü ve adezyon etkisini hafif oranda in vitro vikril ve in vivo PDS üzerinde arttırdı.

Anahtar sözcükler: Anastomoz; kitosan; mukavemet gücü, PDS ve Vicryl iplikler; yara iyileşmesi.

Ulus Travma Acil Cerrahi Derg 2018;24(5):405-4II doi: 10.5505/tjtes.2018.59280 